\title{
BUDAYA PESISIR: \\ Perilaku Konsumtif Masyarakat Tambaklorok, Kelurahan Tanjung Mas, Kecamatan Semarang Utara, Kota Semarang
}

\author{
Rini Susiana \\ Kasie Teknologi dan Mutu Pengolahan Hasil Perikanan \\ Dinas Kelautan dan Perikanan Kota Semarang \\ Jalan Pemuda 175, Semarang
}

\begin{abstract}
The coastal community in the Tambaklorok area does not only work as fishermen as their livelihood. This study aims to determine (1) the social stratification of Tambaklorok community, (2) the similarities and differences in consumer behavior of Tambaklorok community, and (3) the characteristics of consumer behavior of Tambaklorok community. The study uses a qualitative approach. Data collection was carried out through in-depth interviews, observation and analyzing documents. Analysis of data uses an interactive model of Miles and Huberman, including data collection, data reduction, drawing conclusion, verification, and data presentation. The result shows that social stratification of Tambaklorok community based on livelihood, namely the fishermen, fish distributors, fish processors, and civil servants. There are various similarities and differences in consumer behavior of Tambaklorok community seen from the income, expenses and debts. Characteristics of consumer behavior of Tambaklorok community that is impulsive purchasing, includes buying the product in order to maintain personal appearance and prestige as well as of chasing the prize.
\end{abstract}

Key words: consumer habit, fishermen, Tambaklorok community, Semarang. 


\section{Pendahuluan}

Kota Semarang merupakan wilayah pesisir di Pulau Jawa yang terletak antara $6^{\circ} 50^{\prime}-7^{\circ} 10^{\prime} \mathrm{LS}$ dan garis $109^{\circ} 50^{\prime}$ $110^{\circ} 35^{\prime} \mathrm{BT}$, yang secara administratif dibatasi oleh sebelah utara Laut Jawa, sebelah selatan Kabupaten Semarang, sebelah barat Kabupaten Kendal dan sebelah timur Kabupaten Demak. Wilayah pesisir kota Semarang terdiri atas 4 (empat) kecamatan pesisir, salah satunya adalah Kecamatan Semarang Utara. Terdapat 9 (sembilan) kelurahan untuk wilayah kecamatan Semarang Utara dan salah satunya adalah Kelurahan Tanjung Mas. Kelurahan Tanjung Mas terbagi atas dua kampung atau kawasan yakni Tambaklorok dan Kebonharjo (BPS, 2015).

Masyarakat pesisir adalah sekelompok masyarakat yang hidup dan bertempat tinggal di pinggir pantai dan bekerja di laut, dengan mata pencaharian mayoritas sebagai nelayan (Kusnadi, 2006). Di wilayah ini sebagian besar masyarakatnya hidup dari mengelola sumber daya pesisir dan laut baik secara langsung maupun tidak langsung. Maka dari itu perspektif mata pencaharian masyarakat pesisir tersusun dari kelompokkelompok masyarakat yang beragam seperti nelayan, pedagang ikan, pemilik toko, pengolah hasil perikanan, dan Pegawai Negeri Sipil (PNS).

Kampung Tambaklorok merupakan perkampungan nelayan yang terletak di garis pantai Laut Jawa dan dinyatakan sebagai kampung nelayan terbesar di Kota Semarang (Hakim, 2016). Fungsi utama kampung Tambaklorok adalah sebagai kawasan pemukiman, pertambakan dan perdagangan hasil laut (Dimitra dan Yuliastuti, 2012). Kampung Tambaklorok terletak di Kelurahan Tanjung Mas di Kecamatan Semarang Utara. Kampung Tambaklorok terletak dekat wilayah penghubung kegiatan fungsi-fungsi utama Kota Semarang, seperti kawasan Pelabuhan Tanjung Emas, pergudangan, pusat kota lama, Stasiun Kereta Api Semarang Tawang, serta pusat permukiman (Fikadiana, 2001). Keberadaan kawasan pesisir memiliki arti yang strategis.
Salah satu prioritas pengembangan di wilayah pesisir antara lain peningkatan permukiman pesisir.

Masyarakat kawasan pesisir Tambaklorok menjalankan mata pencaharian sebagai nelayan, pedagang ikan, pengolah hasil perikanan, dan ada pula yang bekerja di bidang pemerintahan menjadi Pegawai Negeri Sipil (PNS) atau Aparat Sipil Negara (ASN). Potensi yang ada di kawasan Tambaklorok adalah adanya pelaku usaha di bidang perikanan, seperti mengolah hasil tangkapan dari nelayan menjadi aneka olahan seperti krupuk udang, krupuk ikan, terasi, nugget ikan, bandeng presto, ikan panggang, ikan asin, ikan teri kering dan rebon kering.

Pada setiap wilayah, termasuk wilayah pesisir di Tambaklorok, terdapat pelapisan sosial dalam masyarakat. Dalam proses pelapisan sosial pada masyarakat kota dan desa sangat berbeda. Pada dasarnya Desa secara geografis merupakan tempat yang sangat agraris sehingga menuntut masyarakatnya banyak bekerja sebagai petani, dengan karakteristik masyarakat tradisional dan homogen serta mempunyai sistem kekerabatan yang sangat kuat antar kelompok masyarakat satu dengan yang lainnya, berbeda dengan proses pelapisan sosial pada masyarakat kota di mana satu ciri khas yang melekat pada masyrakat ini adalah industrialis dan faktor ekonomi lebih mendominasi pada setiap kelompok masyarakat (Narwoko dan Suyanto, 2010).

Perbedaan ini dapat dilihat secara jelas dengan cara membanding- bandingkan dari proses pembentukan lapisan sosial pada setiap masyarakat yang beranekaragam. Keadaan ini pada gilirannya menciptakan beberapa tipologi masyarakat yang mempunyai karakteristik masing-masing mulai dari masyarakat yang sederhana hingga masyarakat yang bentuknya kompleks, sehingga mempunyai dampak yang sangat mempengaruhi kehidupan sosial-budaya.

Pelapisan sosial pada masyarakat Tambaklorok dalam tulisan ini didasarkan pada mata pencaharian dan perilaku 
konsumtif seperti pendapatan, pengeluaran, dan hutang yang dimiliki. Sementara itu, perilaku kebiasaan konsumtif dapat didefinisikan sebagai perilaku membeli barang atau jasa yang berlebihan, walaupun tidak dibutuhkan (Moningka, 2006). Dahulu orang berbelanja karena ada kebutuhan yang harus dipenuhi. Saat ini orang berbelanja karena berbagai macam sebab, untuk memanjakan diri sendiri, menyenangkan orang lain, membeli sesuatu dengan alasan hari raya, atau karena potongan harga. Bahkan, hanya sekedar gengsi, untuk memperlihatkan eksistensinya sebagai warga status sosial tertentu, dapat berbelanja di tempat " $X$ " dan mampu membeli barang dengan merek ternama. Tanpa disadari, alasan-alasan tersebut membuat seseorang hidup dalam gaya hidup konsumtif.

Pengertian lain mengenai perilaku konsumtif dipaparkan pula oleh Mowen dan Minor (dalam Sumartono, 2002), bahwa perilaku konsumtif adalah suatu perilaku yang tidak lagi didasarkan pada pertimbangan yang rasional, melainkan membeli produk atau jasa tertentu untuk memperoleh kesenangan atau hanya perasaan atau dengan emosi. Pengertian perilaku konsumtif tersebut sejalan dengan pendapat Dahlan, yakni suatu perilaku yang ditandai oleh adanya kehidupan mewah yang berlebihan, penggunaan segala hal yang dianggap paling mahal memberikan kepuasan dan kenyamanan fisik sebesarbesarnya serta adanya pola hidup manusia yang dikendalikan oleh suatu keinginan untuk memenuhi hasrat kesenangan semata.

Berdasarkan fakta-fakta yang telah dipaparkan, maka artikel ini bertujuan untuk mendeskripsikan (1) pelapisan sosial pada masyarakat pesisir Tambaklorok; (2) persamaan dan perbedaan perilaku konsumtif pada masyarakat pesisir Tambaklorok; dan (3) karakteristik perilaku konsumtif pada masyarakat pesisir Tambaklorok.

\section{Metode}

Penelitian ini menggunakan pendekatan kualitatif, dengan sumber data utama yaitu hasil wawancara dengan 6 informan, yang terdiri dari 2 pengolah ikan, 2 nelayan, dan 2 PNS, serta observasi di lapangan, seperti pengamatan terhadap nelayan dan isteri yang sedang mengolah ikan untuk dijual lagi, rumah yang ditinggali, serta barang-barang yang dimiliki. Fokus penelitian ini antara lain; (1) pelapisan sosial masyarakat, (2) pendapatan, (3) pengeluaran, (4) hutang, dan (5) karakteristik perilaku konsumtif.

\section{Lokasi}

Objek artikel ini berlokasi di Tambaklorok, Kelurahan Tanjung Mas, Kecamatan Semarang Utara, Kota Semarang, Jawa Tengah, sebagai kampung yang terkenal dengan istilah kampung nelayan dan telah dicanangkan oleh Presiden Joko Widodo sebagai salah satu kampung wisata bahari di Indonesia (Hakim, 2016). Selain itu, kampung Tambaklorok ini memiliki beberapa kelompok pengolahan, yaitu pengolahan ikan dan salah satunya pernah mendapat juara dua pada perlombaan Optisarkan tingkat nasional pada masa Presiden Susilo Bambang Yudhoyono. Teknik cuplikan dalam penelitian ini adalah teknik purposive sampling, karena peneliti sudah memiliki kriteria informan yang akan diambil berdasarkan mata pencahariannya. Teknik pengumpulan data dilakukan melalui wawancara mendalam, observasi, dan studi dokumentasi.

Mengacu pada keabsahan data yang ingin diperoleh, maka penelitian ini menggunakan teknik triangulasi sumber dan triangulasi teori. Triangulasi sumber yaitu dengan melakukan checking data, membandingkan data yang diperoleh dengan data yang lain (Moleong, 2006).

Analisis data dalam penulisan laporan penelitian ini menggunakan teknik analisis interaktif Miles dan Huberman (1992). Analisis interaktif tersebut meliputi pengumpulan data, reduksi data, verifikasi data, dan penyajian data. 
Gambar 1 Model Interaktif Miles dan Huberman

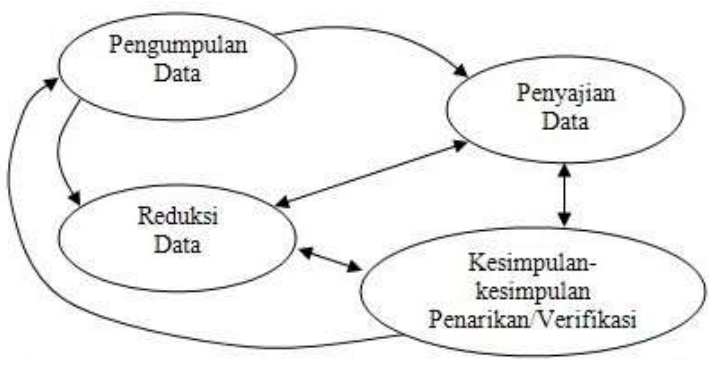

Sumber: Miles dan Huberman, 1992.

\section{Pembahasan}

\subsection{Pelapisan Sosial Masyarakat Tambaklorok}

Dasar pelapisan sosial dapat dilihat dari berbagai unsur. Unsur kekayaan, yakni orang yang memiliki harta paling banyak diurutkan dari lapisan teratas, kekayaan tersebut misalnya penghasilan, harta benda, rumah, tanah, dan sebagainya. Unsur kekuasaan, yakni orang yang memiliki kekuasaan atau yang mempunyai wewenang terbesar atas posisi jabatannya dia akan juga menempati posisi lapisan atas, semakin tinggi jabatan maka semakin besar penghargaan yang diberikan oleh masyarakat. Unsur kehormatan, yakni orang yang paling disegani dan dihormati, mendapat tempat yang teratas, ukuran semacam ini banyak dijumpai pada masyarakat tradisional, biasanya mereka adalah golongan tua atau mereka yang pernah berjasa. Unsur ilmu pengetahuan, yakni orang yang semakin tinggi ilmu pengetahuannya maka semakin tinggi pula peluang posisi dalam menempati posisi lapisan sosial paling atas (Narwoko dan Suyanto, 2010).

Ada pula hal-hal yang mewujudkan unsur dalam teori sosiologi tentang sistem lapisan masyarakat, yakni kedudukan sosial dan peranan. Kedudukan sosial diartikan sebagai tempat atau posisi seseorang dalam suatu kelompok sosial, lingkungan pergaulan, prestise, serta hak dan kewajibannya. Masyarakat pada umumnya mengembangkan dua macam sistem pelapisan sosial berdasarkan kedudukan sosial, yakni Ascribed status atau kedudukan yang diperoleh sejak lahir dan Achieved status atau kedudukan yang dicapai oleh seseorang dengan usaha-usaha yang disengaja (Linton, 1936: 113-131). Sedangkan peranan sosial diartikan sebagai seseorang yang melaksanakan hak dan kewajibannnya sesuai dengan kedudukannya, maka dia menjalankan suatu peranan, dengan begitu peran tersebut menentukan apa yang diperbuatnya bagi masyarakat serta kesempatan-kesempatan apa yang diberikan masyarakat kepadanya. Berdasarkan pelaksanaannya peranan sosial dapat dibedakan menjadi dua, yaitu peranan yang diharapkan (expected roles) dan peranan yang di sesuaikan (actual roles) (Linton, 1936: 113-131; Narwoko dan Suyanto, 2010).

Pada masyarakat Tambaklorok ini, sistem pelapisan sosial dapat didasarkan pada mata pencaharian dan peranannya bagi masyarakat. Semakin tinggi penghasilan seseorang yang didapat dari suatu mata pencaharian, maka semakin tinggi posisi sosial-ekonomi orang tersebut. Sedangkan, semakin besar peranannya bagi masyarakat, seperti membantu dalam pembangunan kampung, sebagai ketua organisasi, dan sebagainya maka semakin besar pula penghargaan atau kehormatan diberikan kepada orang tersebut.

Tabel 1. Pelapisan Sosial Masyarakat Tambaklorok

\begin{tabular}{lc}
\hline \multicolumn{2}{c}{ Pelapisan Sosial } \\
\hline \multicolumn{1}{c}{ Mata Pencaharian } & \multicolumn{1}{c}{ Organisasi } \\
\hline 1. PNS & 1. Ketua Organisasi \\
2. Pengolah Ikan & Poklahsar Mina \\
3. Bakul Ikan & Asri, Poklahsar \\
4. Nelayan & Mina Mandiri, \\
& Komunitas Nelayan \\
& 2. Anggota Organisasi \\
\hline
\end{tabular}

Sumber: Hasil Penelitian, 2016.

Berdasarkan hasil wawancara dan pengamatan, mata pencaharian masyarakat Tambaklorok didominasi oleh nelayan, selanjutnya ada bakul/pengolah ikan, dan PNS. Nelayan dan bakul/pengolah ikan 
berpenghasilan tidak menentu setiap bulannya, bergantung pada musim dan hasil tangkapan ikan. Sedangkan PNS, memperoleh penghasilan tetap setiap bulannya. Bila dilihat pada mata pencaharian, maka PNS terletak pada lapisan teratas, kemudian bakul/pengolah ikan, dan nelayan.

Berbagai mata pencaharian tersebut sebenarnya saling bergantung. Hasil tangkapan nelayan akan mempengaruhi besarnya penghasilan yang didapat bakul ikan dan banyaknya yang dapat diolah oleh pengolah ikan. Untuk PNS karena bertempat tinggal di wilayah pesisir, maka mereka terbiasa dengan menu makanan hasil laut, seperti ikan, udang, cumi-cumi, terasi ikan, krupuk ikan, dan sebagainya.

Dalam masyarakat Tambalorok terdapat dua poklahsar yang berdiri dari tahun 1992, yakni Mina Asri dengan Bu Tumirah sebagai ketuanya dan Mina Mandiri dengan $\mathrm{Bu}$ Aspuriyah sebagai ketuanya. Bu Tumirah dan $\mathrm{Bu}$ Aspuriyah mendapat lapisan teratas pada pelapisan status sosial berdasarkan peranan dan kehormatan. Mereka dapat menyatukan para pengolah ikan dengan membentuk Usaha Kecil dan Menengah (UKM) dan mendukung kegiatan usaha tersebut serta memberi bantuan berupa modal.

Bukan hanya pada pengolah ikan, Pak Hartono sebagai salah satu nelayan di Tambaklorok menempati lapisan teratas pula pada pelapisan sosial berdasar peranan dan kehormatan. Pak Hartono dianggap sebagai sesepuh nelayan di Tambaklorok. Bila ada permasalahan terjadi yang menyangkut nelayan, maka Pak Hartono akan diminta nasehatnya untuk menyelesaikannya. Selain itu, Pak Hartono juga dipercaya oleh Dinas Kelautan dan Perikanan Kota Semarang sebagai perwakilan nelayan dari Tambaklorok. Pak Hartono pun mendapat penilaian baik dari bank karena disiplin dalam pembayaran hutang setiap bulannya.

\section{2. Persamaan dan Perbedaan Perilaku Konsumtif Masyarakat Tambaklorok}

Persamaan dan perbedaan perilaku konsumtif masyarakat Tambaklorok dalam penelitian ini didasarkan pada pendapatan, pengeluaran, dan hutang dari masyarakat dengan pekerjaan yang berbeda.

\section{2. 1. Pendapatan}

Pendapatan yang dimaksud meliputi segala pemasukan keuangan yang diterima selama satu bulan, bukan hanya dari mata pencaharian utama yang dilakoni. Pada pendapatan ini memang terdapat perbedaan dari keenam informan dengan mata pencaharian yang berbeda.

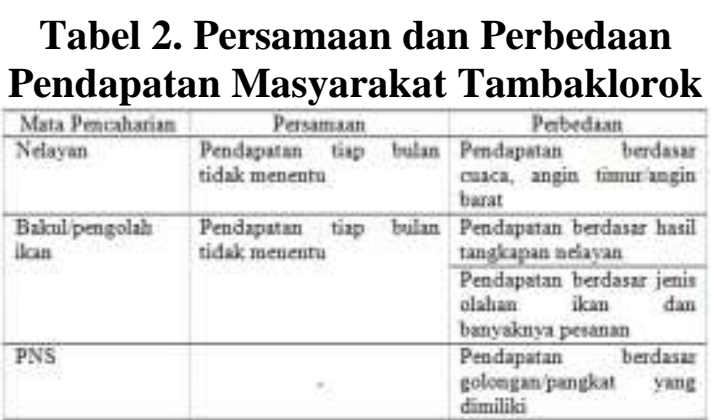

Sumber: Penelitian Lapangan, 2016.

Informan sebagai PNS sudah jelas pendapatannya per bulan melalui gaji yang diberikan oleh pemerintah, besar kecilnya berdasar pada golongan/pangkat yang dimiliki dan tidak memiliki pekerjaan sambilan lainnya. Sedangkan informan sebagai nelayan menyatakan hasilnya tidak menentu, berdasarkan banyaknya hasil tangkapan ikan. Pada saat angin barat yang berhembus, maka akan lebih sedikit pemasukan keuangan yang didapatkan karena kencangnya angin membuat nelayan mengurangi waktunya untuk menangkap ikan, lalu mereka menyiasatinya terkadang mengganti alat tangkap dengan menggunakan sodo yang bentuknya seperti waring. Namun, saat angin timur yang berhembus, maka tangkapan ikan pun akan lebih banyak. Sementara itu, informan sebagai bakul/pengolah ikan pun menyatakan pendapatan yang didapatkan tidak menentu, yakni berdasarkan pada musim panen ikan dan pesanan. 


\section{2. 2. Pengeluaran}

Pengeluaran yang dimaksud meliputi segala pengeluaran keuangan yang tidak hanya untuk kebutuhan sehari-hari. Pada pengeluaran ini pun terdapat perbedaan dan persamaan dari informan dengan berbagai mata pencaharian.

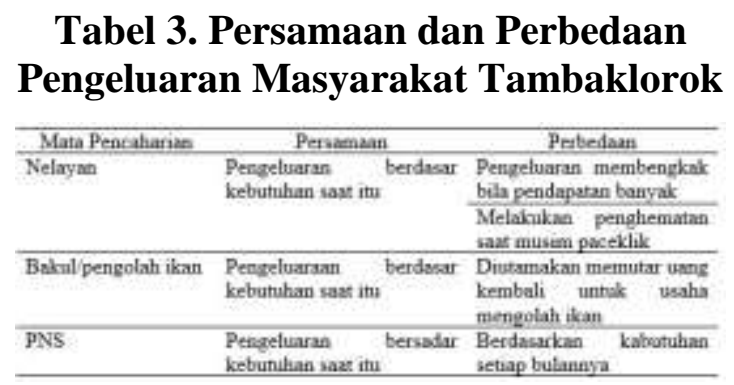

Sumber: Penelitian Lapangan, 2016.

Pengeluaran yang dilakukan berdasar pada besarnya pendapatan yang diperoleh. Informan sebagai nelayan, saat musim paceklik yang berakibat pada kurangnya penghasilan, maka pengeluaran pun hanya sebatas untuk mencukupi makan sehari-hari dan membayar hutang. Namun bila pada saat musim panen ikan, maka mereka akan membeli barang kebutuhan tersier, seperti sepeda motor baru, springbed, lemari es, dan sebagainya. Sedangkan informan sebagai bakul/pengolah ikan sudah lebih dapat memanajemen pengeluaran setiap bulannya untuk memutarkan usaha pengolahan yang sedang dijalankan dan membayar hutang. Bila penghasilan yang diperoleh lebih dari biasanya, mereka akan membeli kebutuhan tersier untuk menunjang penampilan. Sementara itu, informan sebagai PNS, pengeluaran berdasar kebutuhan tiap bulannya dan juga untuk menunjang penampilan, terkadang juga untuk membayar hutang.

\section{2. 3. Hutang}

Hutang yang dimaksud meliputi segala hutang yang tidak hanya untuk kebutuhan mendesak, namun juga dikarenakan sifat konsumtif yang dimiliki. Pada hutang ini pun terdapat perbedaan dan persamaan dari informan dengan berbagai mata pencaharian.

\section{Tabel 4. Persamaan dan Perbedaan Hutang Masyarakat Tambaklorok}

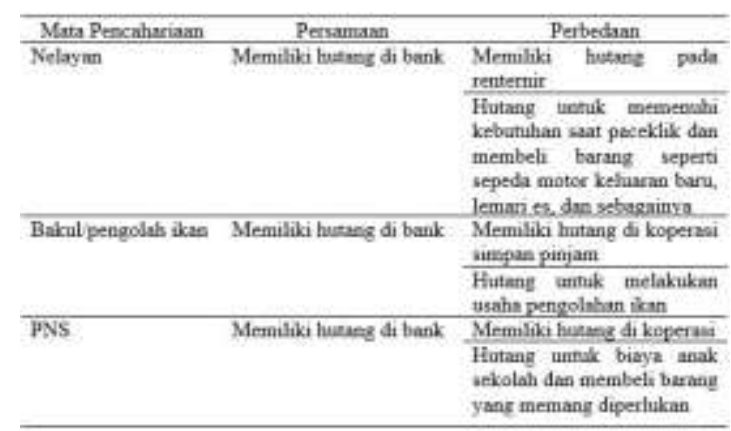

Sumber: Hasil Penelitian, 2016.

Hutang didapatkan dari berbagai sumber, seperti bank, koperasi, bahkan renternir. Tak sedikit pula para nelayan yang memiliki hutang pada renternir, hingga pada saat membayar banyak barang yang terpaksa harus dijual. Informan sebagai nelayan menyatakan bahwa mereka selain berhutang pada bank juga pada rentenir. Alasan memiliki hutang pada rentenir karena lebih mudah tanpa adanya persyaratan seperti di bank, tujuannya untuk gali lubang tutup lubang atau untuk membeli barang-barang lain saat musim paceklik. Sedangkan informan sebagai pengolah/bakul ikan biasa berhutang untuk usaha pengolahan ikan. Mereka biasanya berhutang pada bank dan koperasi simpan pinjam. Sementara itu, informan sebagai PNS biasanya berhutang untuk memenuhi kebutuhan tersier pada saat tertentu. Mereka biasanya berhutang pada bank dan koperasi di tempat kerjanya.

\section{2. 4. Karakteristik Perilaku Konsumtif Masyarakat Tambaklorok}

Temuan pada penelitian ini yang didapatkan dari wawancara dengan informan, pengamatan, serta studi dokumen menunjukkan karakteristik perilaku konsumtif masyarakat Tambaklorok. Perilaku konsumtif masyarakat Tambalorok termasuk pada karakteristik komsumtif pembelian impulsif, yakni pembelian produk dan jasa yang memiliki daya guna bagi individu dan tanpa perencanaan. 
Tabel 5. Karakteristik Perilaku Konsumtif Masyarakat Tambaklorok

\begin{tabular}{|c|c|c|}
\hline \multicolumn{3}{|c|}{ Konsumtif Impulsif } \\
\hline Nelayan & Bakul pengolah ikan & PNS \\
\hline $\begin{array}{l}\text { Membeli barang } \\
\text { karena hadiah }\end{array}$ & $\begin{array}{l}\text { Membeli produk } \\
\text { karena badiab }\end{array}$ & $\begin{array}{l}\text { Membeli produk } \\
\text { kcarena hadiah }\end{array}$ \\
\hline $\begin{array}{l}\text { Membeli produk } \\
\text { untuk menjaga } \\
\text { penampilan dan } \\
\text { gengsi (contoh } \\
\text { lemari es, springbed, } \\
\text { sepeda motor } \\
\text { baru,dII) }\end{array}$ & $\begin{array}{l}\text { Membeli produk } \\
\text { untuk menjaga } \\
\text { penampilan dan } \\
\text { gengsi (contoh } \\
\text { perhuasan,dil) }\end{array}$ & $\begin{array}{l}\text { Membeli produlk } \\
\text { untuk menjaga } \\
\text { penampilan dan } \\
\text { gengsi (contoh } \\
\text { perhuasan, paksian, } \\
\text { mobil,dll) }\end{array}$ \\
\hline
\end{tabular}

Sumber: Hasil Penelitian, 2016.

Perilaku konsumtif impulsif yang dilakukan oleh masyarakat Tambaklorok yang didasarkan pada mata pencaharian pun berbeda-beda. Informan sebagai nelayan mengaku perilaku konsumtifnya pada sebuah barang dan jasa untuk menjaga penampilan dan gengsi, misalkan saja dengan membeli springbed, lemari es, sepeda motor keluaran terbaru. Hal tersebut dilakukan agar tidak kalah dengan tetangga atau nelayan lainnya. Selain itu, mereka mengkonsumsi barang dan jasa pun juga karena unsur hadiah. Misalkan saja mereka banyak membeli produk detergen tertentu karena mendapatkan hadiah piring cantik.

Sedangkan informan kedua yaitu sebagai bakul/pengolah ikan juga membeli produk untuk menjaga penampilan diri dan gengsi. Berbeda dengan nelayan, mereka lebih mementingkan untuk membeli perhiasan, seperti kalung, gelang, dan cincin. Bagi mereka semakin banyak perhiasan yang digunakan maka menunjukkan seberapa besar kemajuan usaha pengolahan yang dijalankan. Selain itu, mereka juga membeli produk karena hadiahnya.

Sementara itu, informan sebagai PNS juga membeli produk untuk menjaga penampilan dan gengsi. Misalkan saja dengan membeli banyak perhiasan, mobil, barang-barang mewah, serta sering melakukan liburan. Bagi mereka, PNS merupakan pekerjaan dengan tingkatan paling tinggi. Selain itu, sama seperti informan lainnya, mereka juga membeli produk karena hadiahnya.

\section{Simpulan}

Pelapisan sosial pada masyarakat Tambaklorok didasarkan pada mata pencaharian dan orang yang dianggap penting dalam suatu komunitas tertentu. Setiap mata pencaharian memberikan perbedaan pada pendapatan, pengeluaran, dan hutang yang dimiliki. Pengeluaran dan hutang dapat menunjukkan karakteristik perilaku konsumtif masyarakat Tambaklorok, yaitu konsumtif impulsif, membeli barang atau jasa tanpa perencanaan. Pembelian produk tersebut untuk menunjang penampilan dan gengsi, serta karena hadiahnya.

Saran diberikan pada masyarakat Tambakorok untuk tidak terjebak hutang pada rentenir karena bunga yang harus dibayarkan sangat tinggi dan lebih dapat menekan perilaku konsumtif. Untuk pemerintah setempat agar lebih memperhatikan masyarakat di daerah pesisir dan menyediakan pinjaman untuk usaha dengan persyaratan yang mudah dan bunga yang rendah.

\section{Daftar Pustaka}

Dimitra, S. \& Yuliastuti, N. 2012. Potensi Nelayan Sebagai Modal Permukiman Berkelanjutan di Tambaklorok, Kelurahan Tanjung Mas. http://eprints.undip.ac.id/42479/ (diunduh 20 November 2016).

Fikadiana, F. 2001. Penataan Permukiman Tambaklorok http://eprints.undip.ac.id/21600/ (diunduh 20 November 2016).

Hakim, Farhan. 2016. Merumuskan Arah Kebijakan Tambaklorok Sebagai Kampung Bahari. http://www.semarangdaily.com/meru muskan-arah-kebijakan-tambakloroksebagai-kampung-bahari.htm (diunduh 20 November 2016).

Kusnadi. 2006. Filosofi Pemberdayaan Masyarakat Pesisir. Yogyakarta: LKiS. 
Linton, Ralph. 1936. "Status and Role," The Study of Man. New York: Appleton.

Miles, B. Mattew dan Huberman, A. Michael. 1992. Analisis Data Kualitatif. Terjemahan Tjetjep Rohendi Rohidi. Jakarta: Universitas Indonesia Press.

Moleong, Lexy J. 2006. Metode Penelitian Kualitatif. Bandung: PT. Remaja Rosdakarya.

Moningka, C. 2006. Konsumtif: Antara Gengsi dan Kebutuhan. http://www.suarapembaruan.com/New s/2006/12/13/urban/urb02.htm (diunduh 20 November 2016).

Narwoko, D. J. \& Suyanto, B. 2010. Sosiologi Teks Pengantar dan Terapan. Jakarta: Kencana Perdana Media Grup.

Sumartono. 2002. Terperangkap dalam Iklan: Meneropong Imbas Pesan Iklan Televisi. Bandung: Penerbit Alfabeta. 